\title{
Crying out blood: haemolacria in a young girl
}

\author{
Deepsekhar Das @ ( , Madhu Chiranthan, Rachna Meel, Swechya Neupane
}

Dr. Rajendra Prasad Centre for Ophthalmic Sciences, All India Institute of Medical Sciences, New Delhi, Delhi, India

\section{Correspondence to Dr Deepsekhar Das; doc.deep.das@gmail.com}

Accepted 17 May 2020

\section{DESCRIPTION}

An 11-year-old girl was brought to our clinic by her mother with the history of blood tinged tears from both eyes for the past 1 week (video 1 ). She also presented the history of one episode of nasal bleeding in the past. When asked about her symptoms, she stated that the bouts were spontaneous, occurring two times per day lasting for periods of 2-3 min and not associated with any stress or cry. She was of premenarcheal age and did not have any menstrual history. There was no history of any systemic illness or medicine intake, and trauma in the past.

On general examination, she was of average build. Her vitals were within normal limits. There was no evidence of pallor or icterus.

On ocular examination, she had an unaided visual acuity of $20 / 20$ in both eyes. On slit lamp examination, both anterior and posterior segments were found to be normal.Intraocular pressure was within normal range. Regurgitation test was negative; lacrimal gland and sac area were found to be normal.

The patient was kept under observation for 2 days and it was seen that every day, 2-3 episodes of blood tinged tearing was taking place (videos 2 and 3 ), each episode lasting for nearly $3 \mathrm{~min}$.

Blood investigations were performed. Complete blood count, bleeding time, clotting time, prothrombin time, activated partial thromboplastin time, international normalized ratio, random blood sugar, liver and renal function tests were found to be within normal limits. In order to rule out any lacrimal gland or drainage pathologies, contrastenhanced CT of orbit and paranasal sinuses was done, which came out to be normal. Cytological examination of tear film showed only red blood cells, with no other abnormal cells.

After performing all the necessary systemic investigations and evaluating for other causes of haemolacria, which came out to be negative, idiopathic cause was attributed to the condition. Her family

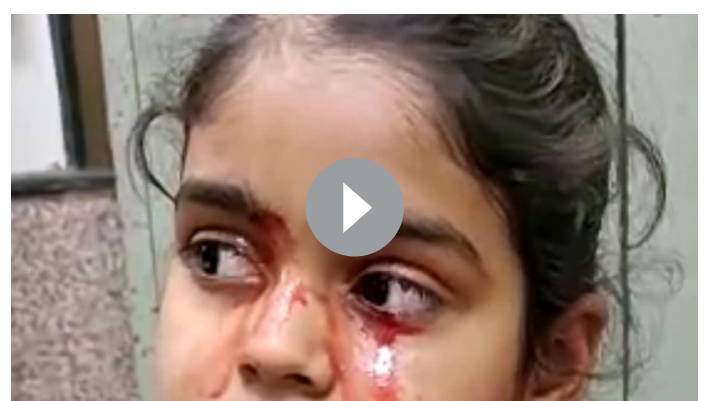

Video 1 Video at presentation

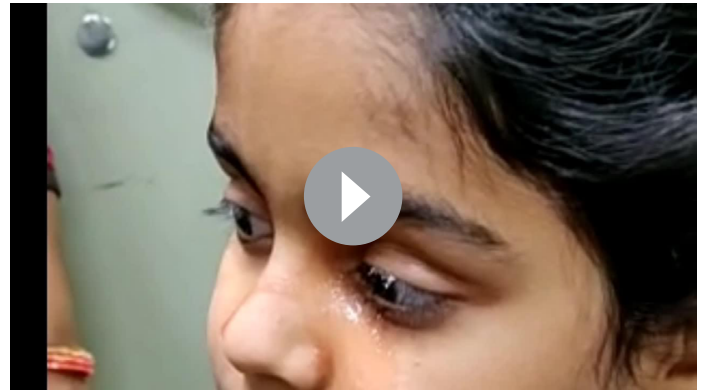

Video 2 First episode of spontaneous haemolacria when under observation

was counselled properly regarding the disease and she has been on follow-up.

Haemolacria is a condition characterised by the presence of blood in tears. The condition is also known as dacryohemorrhea, haemato-dacryorrhea and sanguineous lacrimation. ${ }^{1}$ It is one of the most alarming and rare conditions, which has been attributed to several etiologies. Due to its low incidence and limited literature, the prevalence and predilection of haemolacria for a specific gender, race or age remain obscure. Haemolacria was first mentioned in the scientific medical book, Aëtius of Amida, in the sixth century. A millennium later, in the 16th century, there was a nun who had auricular and ocular haemorrhages every month instead of menstruating, cited by Brassavola. Later in 1581, a 16-year-old girl was cited by Dondonaeus who had drops of bloody tears instead of menstrual discharge. ${ }^{1}$ Haemolacria is a benign and self-limiting condition. However, it has an association with severe systemic diseases

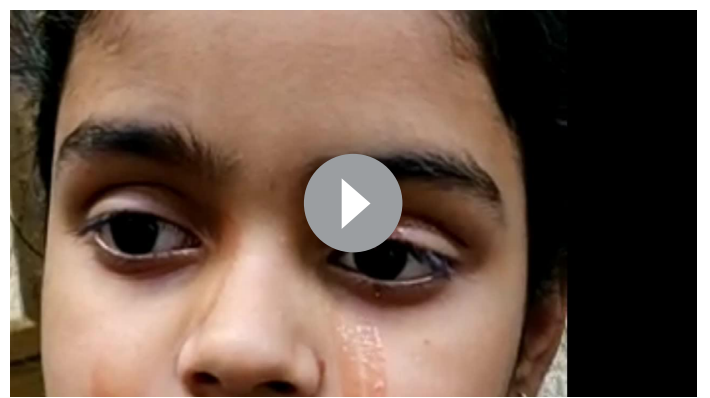

Video 3 Second episode of spontaneous haemolacria when under observation

\section{Patient's perspective}

I am scared about my daughter's health. The blood coming from her eyes is horrifying. I hope there will not be any similar episodes in future. 


\section{Learning points}

- Haemolacria can be seen in many systemic conditions and needs thorough evaluation to rule out any underlying pathology.

- Idiopathic essential haemolacria is diagnosed when no cause is found.

- Idiopathic essential haemolacria has a benign course and patients need to be counselled properly and followed up regularly.

like hereditary haemorrhagic telangiectasia or Osler-WeberRendu disease, Henoch-Schönlein purpura, Gardner-Diamond syndrome and bleeding disorders like haemophilia, characterised by deficiency of clotting factors like VIII and IX. Vascular causes like high blood pressure is one of the common causes of epistaxis. Epistaxis with retrograde flow of blood through puncta lacrimalia has been reported as a cause of haemolacria. ${ }^{2}$ Ocular conditions like conjunctival varicose vessels, inflammatory conditions like blepharitis, conjunctivitis, dacryoadenitis, inflammatory papillomas of conjunctival sac and episcleritis with bloody tears have been reported. Neoplasms like conjunctival hemangioma, meningioma of lacrimal sac and lymphangioma in upper cul-de-sac are also important causes of haemolacria. ${ }^{1}$ In haemolacria, sources of blood can be tear glands, the walls of lacrimal basin or puncta lacrimalia. Thorough evaluation should be done in patients of haemolacria before labelling it as idiopathic. Idiopathic haemolacria is basically a diagnosis of exclusion. ${ }^{3}$ According to the literature, other causes of haemolacria are trauma, vicarious menstruation, stress, anxiety, physical exertion, including stooping, bending and coughing. Drugs like silver nitrate and acetylcholine have been reported to cause haemolacria. Close observation and regular follow-up of a patient is helpful in diagnosing a psychiatric condition known as Munchausen syndrome, a rare cause of haemolacria. ${ }^{4}$

Contributors RM, DD and MC participated in the diagnosis and the management of the patient. SN, DD and MC took part in designing and preparing the manuscript under the guidance of RM.

Funding The authors have not declared a specific grant for this research from any funding agency in the public, commercial or not-for-profit sectors.

Competing interests None declared.

Patient consent for publication Parental/guardian consent obtained.

Provenance and peer review Not commissioned; externally peer reviewed.

\section{ORCID iD}

Deepsekhar Das http://orcid.org/0000-0002-4446-0274

\section{REFERENCES}

1 Murube J. Bloody tears: historical review and report of a new case. Ocul Surf 2011:9:117-25

2 Ahluwalia BK, Khurana AK, Sood S. Bloody tears (haemolacria). Indian I Ophthalmol 1987:35:41.

3 Pujari A, Bajaj MS. Idiopathic bilateral haemolacria. BMJ Case Rep 2016;2016:bcr2016218342.

4 James R, Bharadhi M, James J. Haemolacria in a 22-year-old boy. BMJ Case Rep 2018;11:e225151.

Copyright 2020 BMJ Publishing Group. All rights reserved. For permission to reuse any of this content visit

https://www.bmj.com/company/products-services/rights-and-licensing/permissions/

BMJ Case Report Fellows may re-use this article for personal use and teaching without any further permission.

Become a Fellow of BMJ Case Reports today and you can:

- Submit as many cases as you like

- Enjoy fast sympathetic peer review and rapid publication of accepted articles

- Access all the published articles

Re-use any of the published material for personal use and teaching without further permission

Customer Service

If you have any further queries about your subscription, please contact our customer services team on +44 (0) 2071111105 or via email at support@bmj.com.

Visit casereports.bmj.com for more articles like this and to become a Fellow 